\title{
Numerical taxonomy of bacterial communities associated with a subantarctic mussel bed
}

\author{
M. Bouvy \& D. Delille \\ Laboratoire Arago, Université P. et M. Curie; U.A. 117, F-66650 Banyuls sur mer, France
}

\begin{abstract}
A large mussel bed occurs in one of the largest fjords in Kerguelen archipelago. In January 1986, seawater and bivalves were collected at four tidal levels to determine whether a specific heterotrophic bacterial community could be observed in the mussels, especially in the stomach and in the fecal pellets, and to compare these microflora to seawater bacterial communities. The investigation was carried out using morphological and biochemical tests. Test results were analysed by a numerical taxonomic method. Almost all the heterotrophic mesophile isolates, grown on Zobell medium, were non-fermentative Gram-negative rods. The bacterial communities in the mussel fecal pellets were clearly different from the other communities studied. This specific bacterial microflora was characterized by the existence of Vibrionaceae.
\end{abstract}

\section{INTRODUCTION}

Relationships between filter-feeding bivalves and natural bacteria remain a fundamental problem (Tunnicliffe \& Risk, 1977; Manahan \& Richardson, 1983; Stuart et al., 1982; Seiderer et al., 1984; Amouroux, 1986). Subantarctic bacterial microflora show a strong heterotrophic potential activity (Cahet et al., 1986; Delille \& Cahet, 1984; Bouvy et al., 1986). They seem to play a major role in invertebrate nutrition (Delille et al., 1985; Duchène et al., 1987), especially in the Mytilidae (Delille \& Cahet, 1985). The occurrence in Kerguelen Archipelago of a large mussel bed allowed us to begin a wide pluridisciplinary study in a subantarctic area including surveys of hydrological, phytoplanktonic and biological variables, and of bacterial biomass and activity. The ultimate goal of this program is to determine whether bivalves can filter planktonic bacteria with an efficiency great enough for them to be used as a significant source of food. However, complex interactions between ingested planktonic bacteria and the resident bacterial microflora occurred in the mussel digestive system (Seiderer et al., 1984).

The present study involving numerical taxonomic analysis based on morphological and biochemical tests (API 20B System) was carried out to establish (1) the characteristics of planktonic heterotrophic bacterial communities associated with the mussel bed, and to determine (2) if specific heterotrophic bacteria communities exist in the stomach and fecal pellets of Mytilus edulis desolationis, as reported for other subantarctic invertebrates by Duchène et al. (1987) and Bouvy (unpublished data). 


\section{MATERIALS AND METHODS}

\section{Study area}

Kerguelen archipelago $\left(49^{\circ} \mathrm{S}, 70^{\circ} \mathrm{E}\right)$ covers $6500 \mathrm{~km}^{2}$ and has a total coastline of 2800 $\mathrm{km}$. In the south-east area, a complex system of islands and fjords located in Morbihan Bay plays the role of natural collectors of rain and melt waters. The largest of these fjords, Bossiere Fjord, is about $15 \mathrm{~km}$ long and $100 \mathrm{~m}$ wide. The mussel bed studied is located in the uppermost section of this fjord.

Oceanographical data can be found elsewhere (Delille, 1977). In consideration of environmental conditions (e.g. tidal currents), the water column is generally uniformly mixed. Mean temperature of seawater is $1{ }^{\circ} \mathrm{C}$ in winter and $7{ }^{\circ} \mathrm{C}$ in summer, but in exceptional cases the temperature can rise to much higher values. Maximal tidal amplitude is close to $2 \mathrm{~m}$.

\section{Isolation and characterization of the strains}

Samples were collected in the fjord in austral summer (January 1986) at four tidal levels: low tide, flood tide, high tide and ebb tide. At each tidal level, bacterial strains were isolated from the seawater surrounding the mussel bed (SW), and from the stomach (MS) and the fecal pellets (FP) of Mytilus specimens.

Water samples were collected aseptically using glass bottles within $3-4 \mathrm{~cm}$ (at low tide) and $50 \mathrm{~cm}$ (at other tidal levels) above the surface of the mussel bed. Sets of 10 mussels ( 40 to $61 \mathrm{~mm}$ shell length) were gathered and maintained in batches containing $0.22 \mu \mathrm{m}$ filtered seawater at the in situ temperature until treated (within $4 \mathrm{~h}$ ). In the laboratory, the stomach of one of the mussels was aseptically isolated by dissection; fecal pellets of the remaining mussels were pipetted hourly for $24 \mathrm{~h}$ and transferred to sterile tubes containing $0.22 \mu \mathrm{m}$ filtered seawater.

Procedures for the isolation of strains representative of the three bacterial communities were initiated immediately for the seawater and mussel stomach samples and one day after the sampling for fecal pellets samples. This delay was necessary to obtain a sufficient quantity of fecal pellets; this interval between sampling and plating seems not seriously to affect the composition of bacterial population (Imbaud, 1985). After appropriate dilutions, isolation of aerobic heterotrophic bacteria was made by the spread plate technique with 2216E medium (Oppenheimer \& Zobell, 1952). All the isolates (about thirty per dish), obtained after an incubation of 10 days at $18^{\circ} \mathrm{C}$, were subcultured on marine agar plates (same medium as above) until the purity and viability of each isolate were sure. In more polar conditions (Terre Adelie area; $66^{\circ} 40^{\prime} \mathrm{S}, 140^{\circ} 01^{\prime} \mathrm{E}$ ), we have found small differences between viable numeration results and taxonomical analysis conducted on strains obtained after incubation for 21 days at $4{ }^{\circ} \mathrm{C}$ and for 6 days at $20^{\circ} \mathrm{C}$ (Delille et al., 1988).

A total of 363 representative strains were maintained throughout the study. The distribution of isolated strains from the three heterotrophic bacterial communities at each tidal level is reported in Table 1. For taxonomic analysis, the 27 characters of the API 20B system were used for each strain (API System S.A., La Balme les Grottes, 38390, Montalieu Vercieu, France). The API 20E system has been successfully used in the 
Table 1. Numbers of isolated strains for the three heterotrophic bacterial communities (surrounding seawater; mussel stomach; mussel fecal pellet) studied at each tidal level. Tidal level: flood tide (F.T.); high tide (H.T.); ebb tide (E.T.); low tide (L.T.)

\begin{tabular}{|lccc|}
\hline & $\begin{array}{c}\text { Surrounding } \\
\text { seawater }\end{array}$ & $\begin{array}{c}\text { Fecal } \\
\text { pellets }\end{array}$ & $\begin{array}{c}\text { Mussel } \\
\text { stomach }\end{array}$ \\
\hline F.T. & 29 & 29 & 30 \\
H.T. & 30 & 28 & 31 \\
E.T. & 31 & 32 & 32 \\
L.T. & 31 & 30 & 30 \\
Total & 121 & 119 & 123 \\
\hline
\end{tabular}

natural environment for enteric bacteria (Le Chevalier et al., 1983). A new pattern of this system (SXT or API 20B), specific to environmental research, was developed explicitly by Baleux (1977). The API 20B culture medium contains only $0.5 \% \mathrm{NaCl}$. Therefore, a salinity of $34 \%$, was established aseptically in culture medium for our marine bacteria. The physiological and biochemical tests (detailed in Baleux, 1977) were performed on each isolated strain (see abbreviations for tests in legend in Fig. 1). The presence of $\beta$ galactosidase was detected by the presence of orthonitrophenol from hydrolysis of "OrthoNitroPhenyl $\beta$ D Galactopyranoside" (test called ONPG). The utilization of carbohydrates by bacteria represents an acid production from carbohydrates by an enzymesubstrate reaction. The average index of carbohydrates utilization (12 tests) was noted U.A.I. (Utilization Average Index).

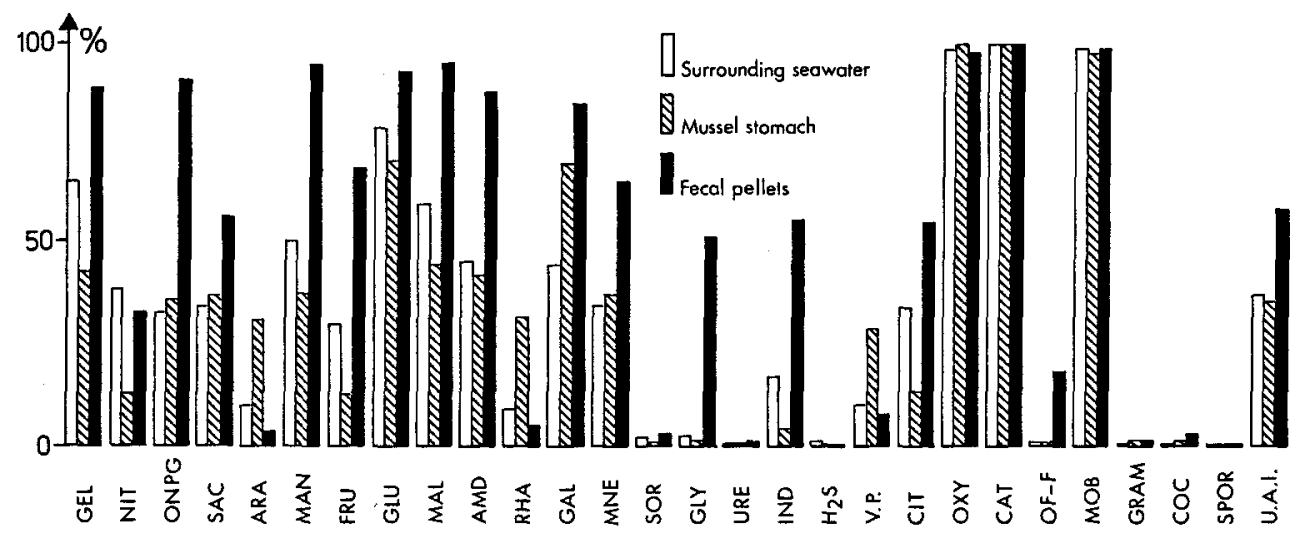

Fig. 1. Diagram showing the percentages of positive responses (API 20B tests) disregarding the tidal stage for the three heterotrophic bacterial communities. Test abbreviations: Hydrolysis of gelatin (GEL); nitrate reductase (NIT); Presence of $\beta$ galactosidase called ONPG; Carbohydrate utilization: saccharose (SAC); arabinose (ARA); mannose (MAN); fructose (FRU); glucose (GLU); maltose (MAL); starch (AMD); rhamnose (RHA); galactose (GAL); mannitol (MNE); sorbitol (SOR); glycerol (GLY). The average index of carbohydrates utilization (12 tests cited above) was noted U.A.I. Urease (URE), indole (IND), $\mathrm{H}_{2} \mathrm{~S}$ and acetoine (VP) productions; citrate utilization (CIT); oxydase (OXY) and catalase (CAT); oxydative and fermentative test (OF-F); motility (MOB) and Gram tests; presence of cocci (COC) and spores (SPOR) 
Convenient for routine studies (Iniss \& Mayfield, 1979; Di Siervi \& Mariazzi, 1982), this method represents a substantial improvement over more tedious procedures available some years ago (Trousselier \& Legendre, 1981).

The simple matching coefficient of Sokal \& Michener (1958) in association with the W.P.G.M. (weight-pair-group-median) algorithm (Sneath \& Sokal, 1974) was used for the numerical taxonomic analysis.

\section{RESULTS}

The diagram in Figure 1 shows distinct responses in the three bacterial communities studied (surrounding seawater, stomach and fecal pellets of mussel), disregarding the tidal stages. Almost all of the isolates were Gram-negative rods. The majority was motile, and catalase and oxidase positive. Some of them (18.3\% of fecal pellet isolates) used glucose fermentatively and they belonged to the Vibrionaceae. However, fecal pellet bacterial communities showed clear differentiations compared with the other communities studied:

- great proportion of indole production from tryptophane $(65.9 \%)$;

- existence of $\beta$-galactosidase from ONPG test $(91.2 \%)$;

- better utilization (close to $100 \%$ ) for several carbon compounds as sole source of carbon (MAN, GLU, MAL, AMD, GAL).

Seawater and mussel stomach bacterial communities showed slight differences. Seawater bacteria were distinguished by their ability to utilize only some organic compounds (unable to use other compounds such as ARA, RHA, SOR, GLY). Stomach bacteria were

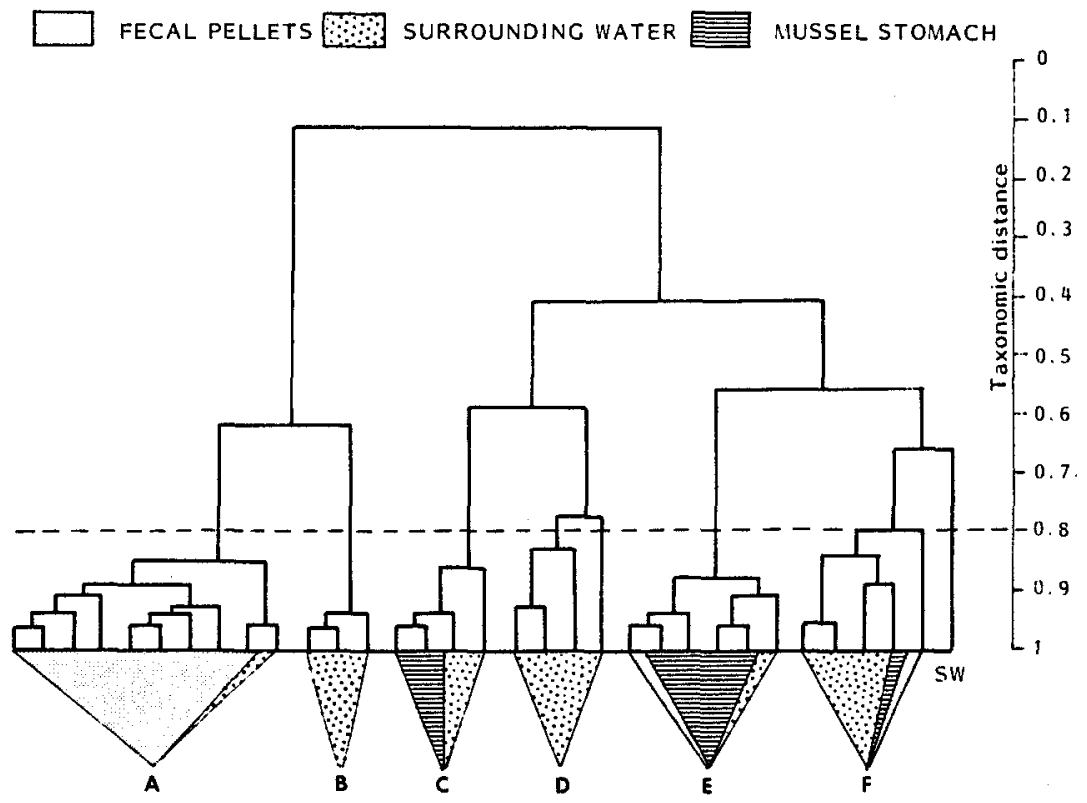

Fig. 2. Hierarchical classification of the 91 strains isolated from the three heterotrophic bacterial communities at low tide. Letters ( $A$ to $F$ ) are the different clusters. $S W=$ non clustered strain isolated from surrounding seawater 


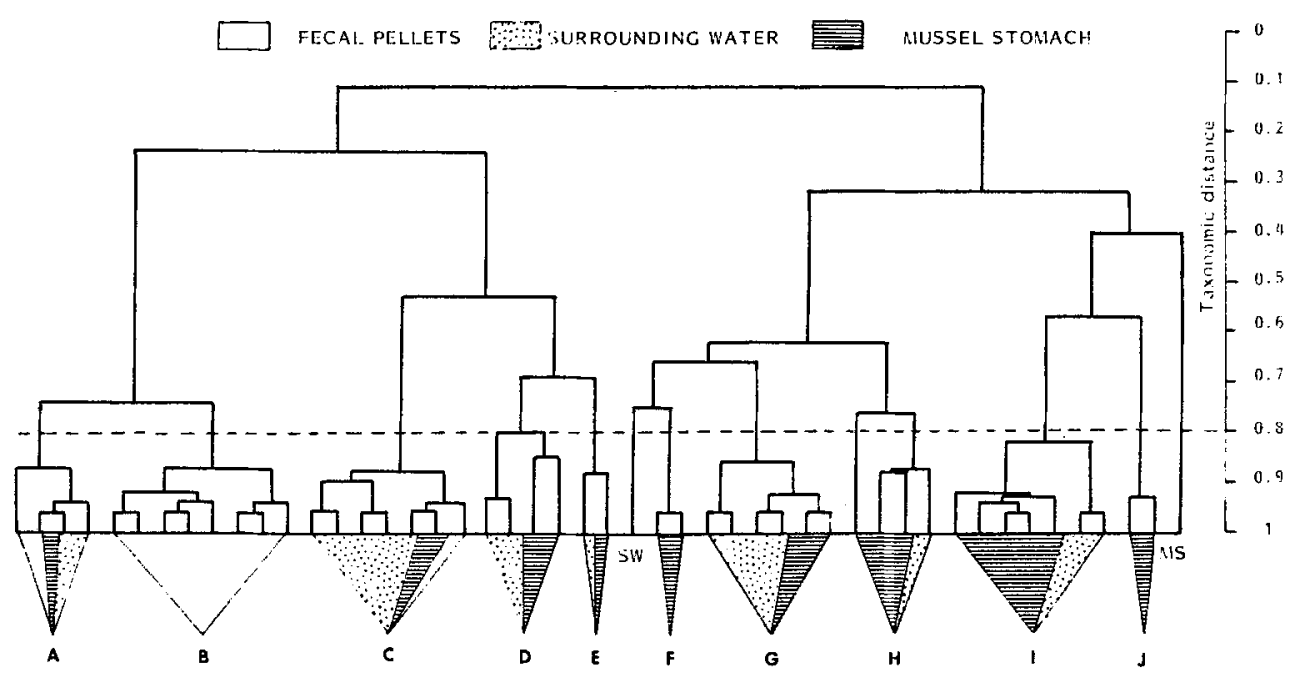

Fig. 3. Hierarchical classification of the 88 strains isolated from the three heterotrophic bacterial communities at flood tide. Letters (A to $\mathrm{J}$ ) are the different clusters. MS and $\mathrm{SW}=$ non clustered strains isolated, respectively, from mussel stomach and surrounding seawater

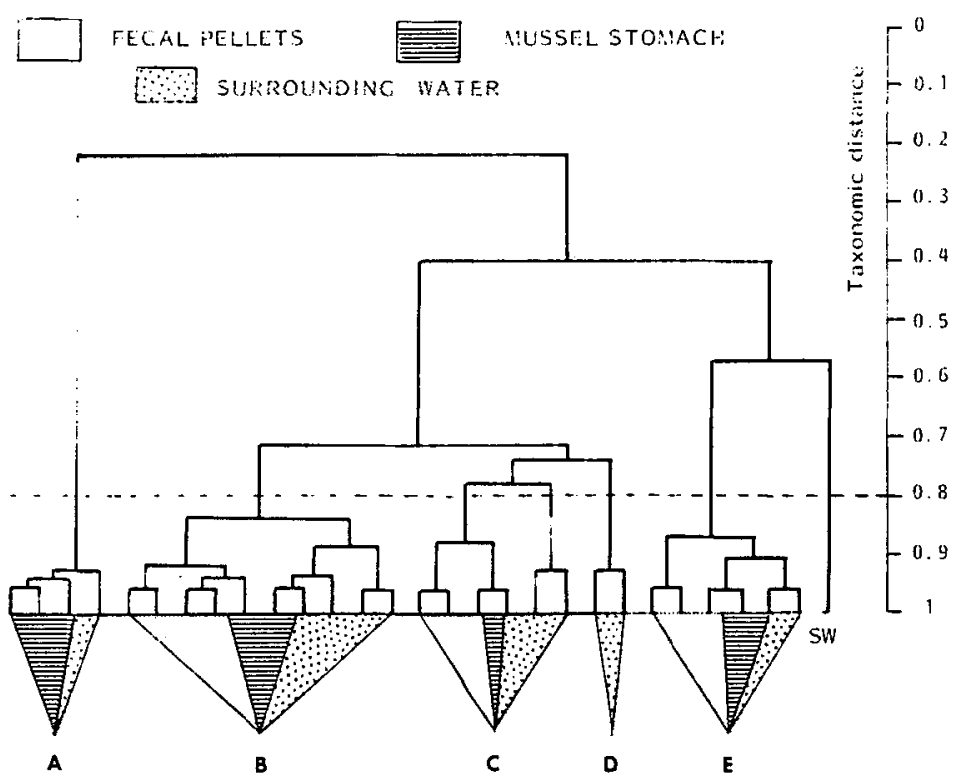

Fig. 4. Hierarchical classification of the 89 strains isolated from the three heterotrophic bacterial communities at high tide. Letters ( $A$ to $E$ ) are the different clusters. $S W=$ non clustered strain isolated from surrounding seawater 
more homogenous in their carbonaceous metabolism; they utilized organic compounds with a percentage of positive responses between 30 to $70 \%$, except for the FRU test.

Numerical taxonomic analysis, conducted on results obtained in the four tidal stages, gave the four dendrograms reported in Figures 2, 3,4 and 5. A total of $98 \%$ of the isolates clustered at a $80 \%$ level of similarity. Only one or two isolates of each analysis failed to cluster at this level (noted I).

\section{Bacterial communities at different tidal levels}

Low tide (Fig. 2): All bacteria included in cluster A were identifiable with Vibrionaceae. With the exception of one isolate, these bacteria were isolated from the fecal pellets. All the other bacteria were non-fermentative Gram-negative rods. Members of clusters $B$ and $D$ were all identified as seawater isolates. Two clusters ( $E$ and $F$ ) were strongly influenced by one bacterial community origin ( $78 \%$ of stomach isolates for $E$ and $72 \%$ of water isolates for F). Cluster $\mathrm{C}$, which included a mixed community (close to $50 \%$ of seawater and stomach isolates), contained only inert isolates $(0 \%$ of positive responses of carbon compounds utilization).

Thus, although few clusters were distinguished ( 6 clusters), the studied bacterial communities at low tide revealed clear physiological and biochemical particularities.

Flood tide (Fig. 3): Excepting one Micrococcus. strain isolated from the stomach which failed to cluster at the $80 \%$ level of similarity, all the isolates were non-fermentative Gram-negative rods. Three clusters contained only isolates of a single origin (B: fecal pellets; F and J: stomach). While fecal pellet isolates were well discriminated (26 of 29 total strains in the same cluster $B$ ), seawater and stomach isolates were mixed in 6 clusters (A, D, E, G, H and I).

Thus, bacterial communities at flood tide were more diversified (ten clusters) but appeared homogeneous for organic compound utilization.

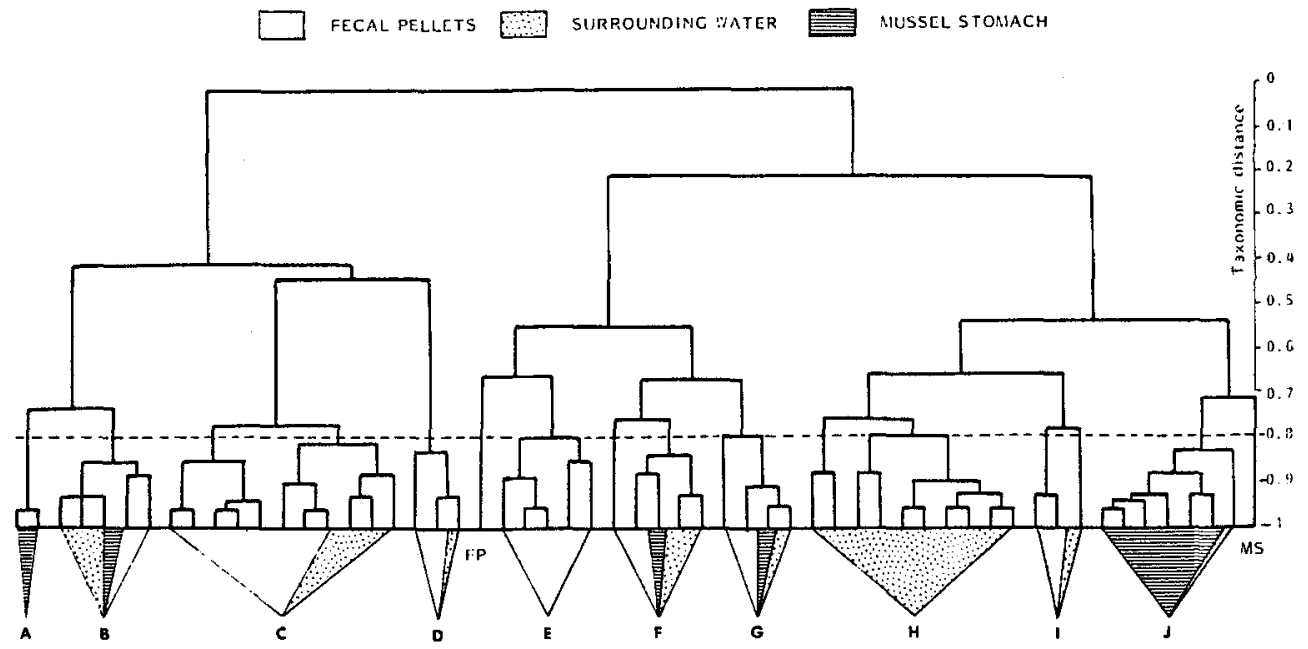

Fig. 5. Hierarchical classification of the 95 strains isolated from the three heterotrophic bacterial communities at ebb tide. Letters (A to $\mathrm{J}$ ) are the different clusters. FP and MS = non clustered strains isolated, respectively, from mussel fecal pellet and mussel stomach 
$\mathrm{High} \mathrm{tide} \mathrm{(Fig.} \mathrm{4):} \mathrm{All} \mathrm{bacteria} \mathrm{isolated} \mathrm{from} \mathrm{the} \mathrm{studied} \mathrm{communities} \mathrm{at} \mathrm{high} \mathrm{tide}$ were non-fermentative Gram-negative rods.

Members included in cluster A were inert isolates. None of the fecal pellet strains were present in this cluster. The smallest cluster D with 2 strains was the only one composed of isolates from one bacterial community (surrounding seawater). The largest cluster B contained more than half of the strains isolated. The rest was distributed over 4 clusters which comprised strains from all of the three samples. Thus, the strain distribution appeared heterogenous.

Ebb tide (Fig. 5): Excepting one Micrococcus strain isolated from fecal pellets, all isolates were non-fermentative Gram-negative bacteria. However, some strains included in cluster $\mathrm{G}$ were coccoid forms and resembled members of the genus Acinetobacter. Other isolates were rod-shaped bacteria.

Members of clusters $A, E$ and $H$ were only strains isolated from, respectively, the stomach, the fecal pellet and the surrounding seawater bacterial communities. Four clusters ( $C, D, I$ and the biggest cluster $J$ with its 27 strains) contained a great proportion of single origin isolates. Three small clusters $(B, F, G)$ were heterogeneous because they comprise strains from all three samples. Thus, the studied bacterial communities at ebb tide appeared well differentiated.

\section{DISCUSSION}

The predominance of non-fermentative Gram-negative rods in subantarctic bacterial communities confirmed the preliminary results obtained in this zone (Delille \& Cahet, 1985; Lemoine, 1985). This fact was previously reported in temperate (Bianchi, 1981) and tropical area (Simidu et al., 1980; Sugahara et al., 1984) and in high latitudes (Hauxhurst et al., 1981). Thus, this observation appears a fundamental characteristic of seawater marine ecosystems. However, if Gram-negative rods are always dominant, fermentative strains are also reported in the antarctic zone (Tanner \& Herbert, 1982).

Some strains of Gram-negative cocci were identifiable with genus Acinetobacter. In this study, such isolates clustered with other gram-negative rods (see Fig. 5, cluster G). This enabled us to confirm the slight difference between some natural coccoid and rodshaped bacterial forms (Novitsky \& Morita, 1976; Ammerman et al., 1984; Delille \& Lemoine, 1987). Often noted in other subantarctic samples, these strains appeared as a trend of degenerative community (Imbaud, 1985). The low proportion of this type of isolate in our study could be an indication of a high metabolic activity of the bacterial community. A confirmation of this hypothesis can be found in the average U.A.I. values obtained in this study which were higher than those reported by Imbaud (1985) for other Morbihan Bay samples. Our U.A.I. notion corresponds to the average index of carbohydrates utilization (12 tests of the 27 characters of API 20B system). However, other indices such as the nutritional versatility index (Hauxhurst et al., 1981) and the average carbon compound index (Martin \& Bianchi, 1980) have been developed. A direct comparison, however, is not possible because different and more numerous substrates were used in calculating their percentages. But great similarities may be noted between their overall results and our estimations. With a mean U.A.I. value of $59 \%$, the heterotrophic bacterial microflora of fecal pellet appeared more active than the seawater and stomach heterotrophic microflora (respectively 37 and $36 \%$ for U.A.I.). These last percentages were 
quite similar to mean values reported by Martin \& Bianchi, 1980 (40\% for Mediterranean waters) and Hauxhurst et al., 1981 (51\% for Alaska offshore waters).

The existence of Vibrio strains associated with bivalves has been noted by Colwell \& Liston (1960, 1952), Chakroun (1967) and Martin (1976). This development of a specific bacterial community should not be linked either to a direct consumption or to a direct selective digestion of bacterial strains (Prieur, 1982; 1984). This phenomenon should rather be related to a selective growth of bacteria during the digestive processes in the alimentary tract of mussels. The presence of this specific bacterial community appeared all the more interesting knowing that this genus is very uncommon in natural subantarctic seawater.

Although the isolation procedure of the strains (medium composition, random selection of isolates) neglects some taxonomic groups, the existence of specific heterotrophic bacterial communities in the stomach gland and fecal pellets appeared unquestionable compared to those of surrounding seawater. The differentiation of bacterial communities could be related to the water movement (e.g. tidal level and current) in the fjord. Hydrodynamic conditions also explain, during some periods, the depletion of particulate organic matter above mussel populations (Flechette \& Bourget, 1985). Thus, the proportion of bacteria in the total nutrition of mussels could change over the year. Investigations on the role of planktonic heterotrophic bacteria in mussel nutrition during the different tidal stages are in progress in order to answer the following question: How much of this amount of food source do the mussels assimilate?

Acknowledgements. Our research was supported by the "Terres Australes et Antarctiques Françaises". We gratefully thank P. Imbaud for statistical advice. The authors are grateful to the anonymous reviewers for their critical reading of this manuscript, and their comments thereon.

\section{LITERATURE CITED}

Ammerman, J. W., Fuhrman, J. A., Hagström, A. \& Azam, F., 1984. Bacterioplankton growth in seawater. I. Growth kinetics and cellular characteristics in seawater cultures. - Mar. Ecol. Prog. Ser. 18, 31-39.

Amouroux, J. M., 1986. Comparative study of the carbon cycle in Venus verrucosa fed on bacteria and phytoplankton. I. Consumption of bacteria (Lactobacillus sp.). - Mar. Biol. 90, 237-241.

Baleux, B., 1977. A computer study of the evolution of aerobic bacterial populations in sewage and river waters. - Microb. Ecol. 4, 53-65.

Bianchi, A., 1981. Distribution quantitative et qualitative des populations bactériennes à l'interface eau-sédiment. In: Biogéochimie de la matière organique à l'interface eau-sédiment marin. Ed. par R. Daumas. CNRS, Paris, 269-274.

Bouvy, M., Le Romancer, M. \& Delille, D., 1986. Significance of microheterotrophs in relation to the degradation process of subantarctic kelp beds (Macrocystis pyrifera). - Polar Biol. 5, 249-253.

Cahet, G., Delille, D. \& Vaillant, N., 1986. Evolution à court terme des microflores utilisant les hydrocarbures en milieu subantarctique. Comparaison des systèmes d'incubation naturels et artificiels. - Actes Colloq. IFREMER 3, 655-662.

Chakroun, F., 1967. Contribution à l'étude des microflores bactériennes de la moule Mytilus galloprovincialis. - Bull. Inst. nat. scient. Tech. Océanogr. Pêche Salammbô 15, 1-65.

Colwell, R. R. \& Liston, J., 1960. Microbiology of shellfish. Bacteriological study of the natural flora of Pacific oysters (Crassostrea gigas). - Appl. Microbiol. 8, 104-109.

Colwell, R. R. \& Liston, J., 1962. The natural bacterial flora of certain marine invertebrates. - J. Insect. Path. 4, 23-33. 
Delille, D., 1977. Contribution à l'étude du rôle des populations bactériennes dans les principaux cycles biologiques $(C, N, S, P)$ établis en milieu sédimentaire subantarctique (archipel de Kerguelen). Thèse, Univ. Lyon, $286 \mathrm{pp}$.

Delille, D. \& Cahet, G., 1984. Croissance de populations hétérotrophes subantarctiques soumises à des enrichissements azotés. Effet des hydrocarbures. In: Bacteriologie marine. CNRS, Paris, 213-219.

Delille, D. \& Cahet, G., 1985. Heterotrophic processes in a Kerguelen mussel-bed. In: Antarctic nutrient cycles and food webs. Ed. by W. R. Siegfried, P. R. Condy \& R. M. Laws. Springer, Berlin, $128-135$.

Delille, D. \& Lemoine, G., 1987. Dynamique saisonnière des microflores hétérotrophes marines subantarctiques. Comité national français des recherches antarctiques (in press).

Delille, D., Guidi, L. D. \& Soyer, J., 1985. Nutrition of Allotanais hirsutus (Crustacea: Tanaidacea) at Kerguelen Island. In: Antarctic nutrient cycles and food webs. Ed. by W. R. Siegfried, P. R. Condy \& R. M. Laws. Springer, Berlin, 378-380.

Delille, D., Bouvy, M. \& Cahet, G., 1988. Short-term variations of bacterioplankton in the Antarctic zone: Terre Adelie area. - Microb. Ecol. (In press).

Duchène, J. C., Imbaud, P. \& Delille, D., 1987. Associated microflora of a subantarctic polychaete worm Thelepus setosus. - Arch. Hydrobiol. (In press).

Flechette, M. \& Bourget, E., 1985. Energy flow between the pelagic and benthic zones: factors controlling particulate organic matter available to an intertidal mussel bed. - Can. J. Fish. aquat. Sci. 42, 1158-1165.

Hauxhurst, J. D., Kaneko, T. \& Atlas, R. M., 1981. Characteristics of bacterial communities in the Gulf of Alaska. - Microb. Ecol. 7, 167-182.

Imbaud, P., 1985. Etude de la répartition spatiale d'une population bactérienne hétérotrophe à la surface d'un sable intertidal subantarctique (Archipel de Kerguelen). - Rapp. DEA Univ. Lyon 1, $1-38$.

Iniss, W. E. \& Mayfield, C. I., 1979. Seasonal variation of psychrophilic bacteria in sediment from Lake Ontario. - Wat. Res. 13, 481-484.

Le Chevalier, M. W., Camero, S. C. \& McFeter, G. A., 1983. New medium for improved recovery of coliform bacteria from drinking water. - Appl. environ. Microbiol. 45, 484-492.

Lemoine, G., 1985. Dynamique saisonnière des populations marines en milieu subantarctique (Archipel de Kerguelen). Utilisation des plaquettes API 20B. Thèse, Univ. Reims, 92 pp.

Manahan, D. T. \& Richardson, K., 1983. Competition studies on the uptake of dissolved organic nutrients by bivalve larvae (Mytilus edulis) and marine bacteria. - Mar. Biol. 75, 241-247.

Martin, Y. P., 1976. Importance des bactéries chez les mollusques bivalves. - Haliotis 7, 97-103.

Martin, Y. P. \& Bianchi, M. A., 1980. Structure, diversity and catabolic potentialities of aerobic heterotrophic bacterial populations associated with continuous cultures of natural marine phytoplankton. - Microb. Ecol. 5, 265-279.

Novitsky, J. A. \& Morita, R. Y., 1976. Morphological characterization of small cells resulting from nutrient starvation of a psychrophilic marine vibrio. - Appl. environ. Microbiol. 32, 617-622.

Oppenheimer, C. H. \& Zobell, C. E., 1952. The growth and viability of sixty three species of marine bacteria as influenced by hydrostatic pressure. - J. mar. Res. 11, 10-18.

Prieur, D., 1982. Etude expérimentale de l'installation d'une microflore associée au tractus digestif de la moule, Mytilus edulis (L.). - Publs CNEXO (Actes Colloq.) 13, 97-104.

Prieur, D., 1984. Etude qualitative et quantitative des communautées bactériennes associées aux bivalves marins: comparaisons avec les microflores de l'eau et du sédiment. In: Bactériologie marine. CNRS, Paris, 161-167.

Seiderer, L. J., Davis, C. L., Robb, F. T. \& Newell, R. C., 1984. Utilisation of bacteria as nitrogen resource by kelp-bed mussel Choromytilus meridionalis. - Mar. Ecol. Prog. Ser. 15, 109-116.

Simidu, U., Taga, N., Colwell, R. R. \& Schwarz, J. R., 1980. Heterotrophic bacterial flora of the seawater from the Nansei Shoto (Ryukyo Retto) area. - Bull. Jap. Soc. scient. Fish. 46, 505-510.

Sneath, P. H. A. \& Sokal, R. R., 1974, The principles and practice of numerical classification. Freeman, San Francisco, 359 pp.

Sokal, R. R. \& Michener, C. D., 1958. A statistical method for evaluating systematic relationships. Kans. Univ. Sci. Bull. 38, 1409-1438.

Stuart, V., Field, J. G. \& Newell, R. C., 1982. Evidence for absorption of kelp detritus by the ribbed 
mussel Aulacomya ater using a new $51 \mathrm{Cr}$ labelled microsphere technique. - Mar. Ecol. Prog. Ser. 9, 263-271.

Sugahara, I., Lim, L. C. \& Hooi, K. K., 1984. Heteratrophic bacterial population in tropical coastal waters. - Bull. Jap. Soc. scient. Fish. 50, 1385-1393.

Tanner, C. A. \& Herbert, R. A., 1982. A numerical taxonomic study of gram negative bacteria isolated from the antarctic marine environment. - Publs CNEXO (Actes Colloq.) 13, 31-38.

Trousselier, M. \& Legendre, P., 1981. A functional evenness index for microbial ecology. - Microb. Ecol. 7, 283-297.

Tunnicliffe, V. \& Risk, M. J., 1977. Relationships between the bivalve Macoma balthica and bacteria in intertidal sediments: Minas Basin, Bay of Fundy. - J. mar. Res. 35, 499-507. 